\title{
PENYULUHAN FISIOTERAPI DADA TERHADAP PEMELIHARAAN FUNGSI OTOT PERNAFASAN PADA PASIEN GANGGUAN SISTEM PERNAFASAN DI RUANG PARU RSUD M.ZAIN PAINAN
}

\author{
Rhona Sandra $^{1}$, Honesty Diana Morika ${ }^{2}$, Siska Sakti Anggraini $^{3}$, \\ Harinal Afriesta 4 \\ STIKES SYEDZA SAINTIKA PADANG \\ *Email:sandra.rhona@yahoo.com
}

\begin{abstract}
ABSTRAK
Gangguan pada sistem respirasi seperti Penyakit Paru Obstruksi Kronik (PPOK), Pneumonia Tuberculosis (TB) merupakan kasus yang banyak di jumpai pada pasien yang menjalani perawatan di Rumah Sakit dengan angka $87 \%$. Pada kebanyakan pasien yang mengalami gangguan sistem respirasi pernafasan seperti PPOK, TB dan Pneumoni sering terjadi peningkatan produksi sekret, sputum atau lendir yang mengental, sehingga diperlukan upaya untuk pengeluaran sekret salah satu tindakan yang dapat diberikan adalah teknik fisoterapi dada. Fisioterapi dada merupakan satu cara pengobatan untuk mengembalikan fungsi organ pernafasan dengan cara postural drainage, perkusi dan vibrasi dada (Potter\&Perry,2009). Dengan pemberian fisioterapi dada pada pasien yang mengalami retensi sekret dan gangguan oksigenasi respon yang diharapkan penumpukan sekret dapat dicegah, drainase trakheobronkhial dapat ditingkatkan dan ventilasi dapat diperbaiki (Asih\&Effendy,2004). Kegiatan dari pengabdian ini adalah untuk meningkatkan pengetahuan pasien dan keluarga untuk pengeluaran dan mengurangi produksi sekret pada pasien gangguan respirasi di Ruang Paru RSUD M.Zain Painan. Metode yang digunakan ceramah dan demonstrasi. Kegiatan ini berjalan dengan lancar dan peserta sangat aktif mendengarkan dan melakukan fisioterapi dalam membantu pengeluaran sekret yang menghalangi jalan nafas.
\end{abstract}

Kata kunci : Fisoterapi,Dada, Respirasi

\begin{abstract}
Disorders of the respiratory system such as Chronic Obstructive Pulmonary Disease (COPD), Pneumonia Tuberculosis (TB) are cases that are often encountered in patients undergoing hospital treatment with numbers $87 \%$. In most patients who experience respiratory system disorders such as COPD, TB and Pneumoni often increase the production of secretions, sputum or thickened mucus, so that efforts are needed to remove the secretions. One of the measures that can be given is chest physiotherapy techniques. Chest physiotherapy is a treatment method to restore respiratory organ function by means of postural drainage, percussion and chest vibrations (Potter \& Perry, 2009). By giving chest physiotherapy to patients who experience retention of secretions and impaired oxygenation response, it is hoped that the accumulation of secretions can be prevented, tracheobronchial drainage can be increased and ventilation can be improved (Asih \& Effendy, 2004). The activity of this service is to increase patient and family knowledge for expenditure and reduce secretion production in patients with respiratory disorders in the Lung Room of RSUD M. Zain Painan. The methods used are lectures and demonstrations. This activity runs smoothly and the participants are very active in listening and doing physiotherapy to help remove secretions that block the airway.
\end{abstract}




\section{Jurnal Abdimas Saintika}

Volume 3 Nomor 1 | https://jurnal.syedzasaintika.ac.id

Key words: Physiotherapy, Chest, Respiration

\section{PENDAHULUAN}

Fisioterapi dada adalah salah satu dari pada fisioterapi yang sangat berguna bagi penderita penyakit respirasi baik yang bersifat akut maupun kronis. Fisioterapi dada ini dapat digunakan untuk pengobatan dan pencegahan pada penyakit paru obstruktif menahun, penyakit pernafasan restriktif termasuk kelainan neuromuskuler dan penyakit paru restriktif karena kelainan parenkim paru seperti fibrosis dan pasien yang mendapat ventilasi mekanik. Tindakan keperawatan fisioterapi dada dapat berupa melakukan perkusi dan vibrasi, postural drainase, latihan pernapasan/napas dalam, dan batuk efektif. (Brunner \& Suddarth, 2002)

Fisioterapi dada ini walaupun caranya kelihatan tidak istimewa tetapi ini sangat efektif dalam upaya mengeluarkan secret dan memperbaiki ventilasi pada pasien dengan fungsi paru yang terganggu. (Potter \&perry, 2009)

Fisioterapi dada direkomendasikan untuk pasien-pasien yang produksi sputum lebih dari 30cc per hari atau menunjukkan bukti atelektasis dengan sinar $\mathrm{X}$ dada.Terapi ini terdiri dari drainase postural, perkusi dada dan vibrasi. Fisioterapi dada harus diikuti dengan batuk produktif dan penghisapan pada klien yang mengalami penurunan kemampuan untuk batuk
(Potter\&Perry,2009).

Pasien yang mengalami retensi sekresi dangan gangguan oksigenasi, seperti pneumonia dan PPOK membutuhkan fisioterapi dada untuk mengencerkan dan membuang sekresi. Waktu yang optimal untuk melakukan tehnik ini adalah sebelum pasien makan dan sebelum tidur. Sehingga respon yang diharapkan, pengumpulan sekresi dapat dicegah, drainase traheobranbronkhial dapat ditingkatan dan ventilasi dapat diperbaiki (Asih\&Effendy, 2004).

Pasien dengan secret yang banyak dilakukan perkusi dan drainase postural untuk membuang sekret yang menyumbat, yang menjadi factor predisposisi infeksi( Price\& Wilson, 2006)

Survey yang dilakukan di RSUD M.Zain Painan pada tanggal 1 April 2021 jumlah pasien di ruang paru M.Zein Painan berjumlah 9 orang, yang terdiri dari 1 orang TB Paru, 5 orang Pneumonia, 2 orang CPC, 1 orang dengan Hemaptoe. Tingginya angka atau jumlah pasien yang dirawat inap di bangsal paru RSUD M.Zain Painan, Tim pengabdian masyarakat Dosen STIKES Syedza Saintika tertarik untuk memberikan penyuluhan dan mengedukasi pasien tentang "Fisioterapi dada di Ruang Paru RSUD M.Zain Painan"

\section{METODE}

Metode dalam kegiatan pengabdian berupa penyuluhan dengan cara berikut ini:

\begin{tabular}{|c|l|}
\hline Tujuan & $\begin{array}{l}\text { Kegiatan pengabmas ini bertujuan meningkatkan pengetahuan } \\
\text { pasien dan keluarga dalam membantu mengembalikan dan } \\
\text { memelihara fungsi otot pernafasan dengan membersihkan secret } \\
\text { dari bronkus di Ruang Paru RSUD M.Zain Painan }\end{array}$ \\
\hline Isi Kegiatan & $\begin{array}{l}\text { Memberikan pengetahuan dan mendemonstrasikan tentang cara } \\
\text { melakukan fisioterapi dada untuk pengeluaran sekret }\end{array}$ \\
\hline Sasaran & Pasien dan keluarga yang mengalami gangguan fungsi pernapasan \\
\hline
\end{tabular}




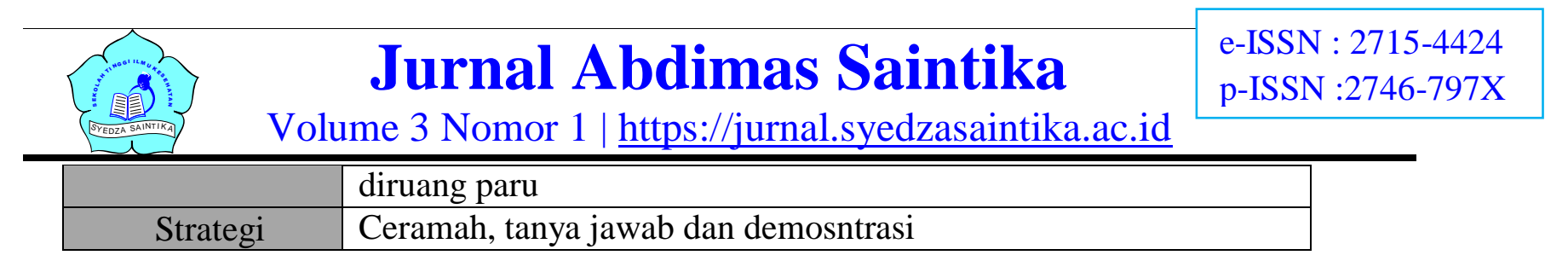

\section{HASIL DAN PEMBAHASAN}

Kegiatan pengabmas ini dilaksanakan pada hari selasa, 6 April 2021, yang dimulai pada pukul 10.00-11.00 WIB. Peserta pasien gangguan sistem pernafasan dan keluarga pasien di Ruang Paru RSUD M.Zain Painan.

1. Tahap persiapan

Persiapan dimulai dari melakukan survei awal di ruang paru dan membuat proposal pengabmas serta meminta izin untuk pelaksanaan pengabmas.

2. Tahap pelaksanaan

Pembukaan dibuka oleh moderator dan menjelaskan tujuan kegiatan. Kemudian dilanjutkan presenter dengan pemaparan materi tentang Fisoterapi Dada.

3. Tahap evaluasi

a. Evaluasi Struktur

Peserta yang hadir sebanyak 8 orang. Penyuluhan berlangsung di Ruang Paru RSUD M.Zain Painan, penggunaan bahasa sudah komunikatif dalam penyampaian, pasien cukup paham dengan apa yang di sampaikan dan Tim Pengabmas mampu memfasilitasi pasien dan keluarga selama berjalannya penyuluhan dan diskusi. Perlengkapan dan alat media yang digunakan sudah lengkap, sesuai dengan yang direncanakan, yaitu dengan menggunakan leaflet, infokus dan laptop

b. Evaluasi Proses

Kegiatan berjalan lancar sesuai rencana, dan kontrak yang telah disepakati di awal pembukaan, pasien aktif dalam kegiatan penyuluhan, penuh perhatian, dan pasien mengajukan pertanyaan mengenai presentasi penyuluhan yang disampaikan, seluruh pasien mengikuti, seluruh pasien mengikuti acara sampai selesai.

c. Evaluasi Hasil

1. $95 \%$ pasien memahami tentang fisioterapi dada

2. $90 \%$ pasien tujuan dilakukan fisioterapi dada

3. $95 \%$ pasien mampu mengenal dan melakukan fisoterapi dada

\section{SIMPULAN}

Kegiatan penyuluhan fisioterapi berjalan dengan lancar, mulai dari persiapan, pelaksanaan dan evaluasi. Peserta sangat antusias dalam mengikuti kegiatan ini terlihat dari banyaknya peserta yang bertanya dan mencoba melakukan teknik fisioterapi dada, yang salah satu tujuannya adalah mengembalikan dan memelihara fungsi otot pernafasan dan membantu pengeluaran secret. Teknik fisoterapi dada ini sangat efektif digunakan pada pasienpasien dengan gangguan sistem pernafasan, diharapkan pemberian fisioterapi dada dapat diberikan dengan teknik-teknik yang bervariasi seperti postural drainage dan vibrasi dada.

\section{DAFTAR PUSTAKA}

Brunner \& Suddart. 2002. Buku Ajar Keperawatan Medikal Bedah. Edisi 8. Alih Bahasa: Agung Waluyo,dkk. Jakarta: EGC.

KusyatiEni Ns, dkk. 2006. Ketrampilan Dan Prosedur Laboratorium KeperawatanDasar. Jakarta: EGC. 


\section{Jurnal Abdimas Saintika}

Volume 3 Nomor 1 | https://jurnal.syedzasaintika.ac.id

Perry, Peterson, Potter. 2005. Buku Saku Ketrampilan Dan ProsedurDasar. Potter, Patricia A. 2005. Buku Ajar

Edisi5.Alih Bahasa: Rosidah,

Fundamental Keperawatan. Jakarta: EGC Monika Ester. Jakarta: EGC. 